\title{
Benthic epifauna assemblages, biomass and respiration in The Gully region on the Scotian Shelf, NW Atlantic Ocean
}

\author{
B. T. Hargrave ${ }^{1, *}$, V. E. Kostylev ${ }^{2}$, C. M. Hawkins ${ }^{3}$ \\ ${ }^{1}$ Marine Environmental Science Division, Department of Fisheries and Oceans, and ${ }^{2}$ Geological Survey of Canada (Atlantic), \\ Department of Natural Resources Canada, Bedford Institute of Oceanography, PO Box 1006, Dartmouth, \\ Nova Scotia B2Y 4A2, Canada \\ ${ }^{3}$ Triton Consultants Ltd, 10 Lakemist Court, Dartmouth, Nova Scotia B3A 4Z1, Canada
}

\begin{abstract}
Epifauna community assemblages were identified by analysis of $35 \mathrm{~mm}$ still pictures taken at 92 stations in The Gully, a submarine canyon on the edge of the Scotian Shelf off Canada's east coast. Numbers of epifauna taxa, seabed type and area of hard (gravel) substrate were measured in images from underwater camera systems. A substrate hardness index, and epifauna community biomass and respiration rates were calculated at 31 stations within The Gully and on adjacent banks using image analysis, volume conversion factors and an empirical allometric regression between wet weight and measured respiration rates for major epifauna taxa. Average turnover time (TT) in days for each location was calculated as energy stored in biomass to calories respired. Non-parametric correlation analysis on dissimilitarity matrices and cluster analysis based on water mass, substrate type and bathymetry distinguished 6 types of benthic habitats and 7 assemblages of co-occurring assemblages for 175 epifauna taxa associated with specific habitat types. Sandy areas on adjacent banks (50 to $300 \mathrm{~m}$ ) were dominated by echinoderms. Stations with glaciomarine sediments near the head of The Gully (100 to $500 \mathrm{~m}$ ), dominated by anemones, sponges and soft corals, had the greatest numbers of taxa. Epifauna biomass and respiration rates were highest where gravel cover was $>50 \%$. There were fewer taxa with lower biomass and respiration in deeper $(>500 \mathrm{~m})$ water. Deep-water brittle stars, hard and soft coral and anemone species predominated where the proportion of hard substrate decreased $(<50 \%)$. Average TT was low (388 and $453 \mathrm{~d}$ ) at stations 200 to $500 \mathrm{~m}$ deep and in the mid-central areas of The Gully, where the percentage of rock cover was $>50 \%$, with a trend to higher values (>600 d) in deeper water. Stations with low TT values were dominated by molluscs. The observations suggest that organically rich particulate matter used by suspension- and depositfeeding epifauna is transported from the head of the canyon and surrounding banks down the axis of The Gully.
\end{abstract}

KEY WORDS: Epifauna - Community - Assemblages · Biomass - Respiration - NW Atlantic · Continental shelf

\section{INTRODUCTION}

Recently, the Sable Island Gully (sometimes referred to as The Gully), a deep (>2500 m) submarine canyon that separates Sable Island Bank from Banquereau on the eastern margin of the Scotian Shelf, the continental shelf off Nova Scotia in the western Atlantic Ocean, has received considerable attention as a candidate for a marine protected area (Harrison \& Fenton 1998, Fenton et al. 2002, Gordon \& Fenton 2002). The region contains a vulnerable population of northern bottlenose whales and is adjacent to an area of active exploration for petroleum development. Physical models and observations have shown that the southward flow 
along the south edge of the Scotian Shelf, that is intensified in spring, results in onshore penetration of water from the shelf-edge into The Gully (Han et al. 2002). Tidal energy dissipation and vertical mixing may provide nutrient enrichment for spring phytoplankton blooms in surface water (Kepkay et al. 2002, Sandstrom \& Elliott 2002). The complex bottom topography results in a variety of benthic habitats ranging from steeply sloped bedrock outcroppings to gravel-dominated glacial till, fine to medium sand, silty-sand and mud bottom types (Amos 1989, Kostylev et al. 2001, Fader \& Strang 2002, Fenton et al. 2002). The distribution of Tertiary and Holocene sediments within inner parts of The Gully canyon system may reflect tidally driven resupension and erosion (Marlow 1965, Jacques Whitford Environmental 2001). Transport appears to occur in a southward direction, with sediment moving from surrounding shelves into the canyon head areas (Amos 1989, Piper et al. 1990, Fader \& Strang 2002).

The distribution of benthic fauna on the Scotian Shelf has been documented in relatively few studies (Nesis 1965, Mills \& Fournier 1979, Pocklington \& Tremblay 1987, Wildish et al. 1989, Kostylev et al. 2001, Stewart et al. 2001). Most studies have been restricted to shallow areas of the Scotian Shelf such as Banquereau, Sable, Emerald, Browns and Western Banks, and are primarily descriptive in nature. Few investigations have examined benthic fauna in deeper $(>400 \mathrm{~m})$ areas, although it is known that other sub-

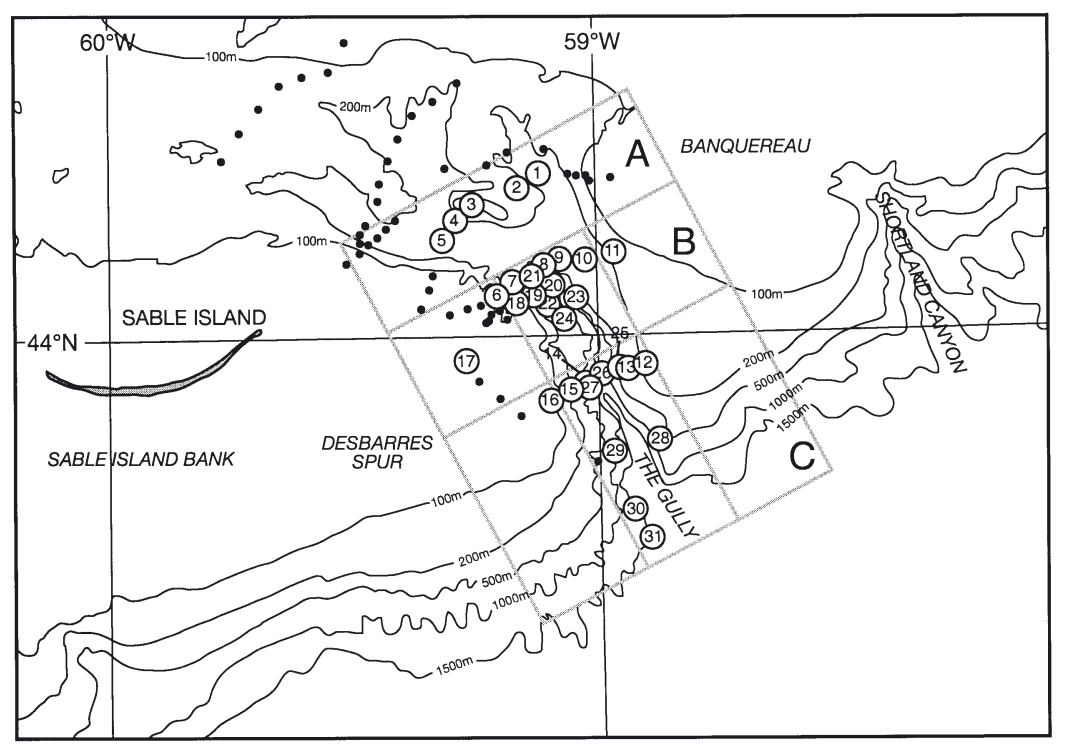

Fig. 1. Location of 92 stations $(\bullet)$ in The Gully region of the Scotian Shelf $\left(44^{\circ} \mathrm{N}\right.$, $59^{\circ} \mathrm{W}$ ) photographed for analysis of epifauna benthic assemblages and related benthic environmental variables in 1997, 1999 and 2000. Estimates of epifauna biomass, calculations of respiration rates and turnover times were made at 31 (numbered) stations. Boxes group stations into (A) inner, (B) middle and (C) outer regions of The Gully marine canyon environments on shelves show higher abundance and biodiversity than adjacent slope areas (Hecker et al. 1980, Houston \& Haedrich 1984, Duineveld et al. 2001).

Although surveys of commercial fish, invertebrates and plankton have been conducted in The Gully (Harrison \& Fenton 1998, Keizer 1998), there is little information on epibenthic faunal communities. Our study utilized still photographic images obtained in 1997 , 1999 and 2000 to describe the distribution of benthic epifauna in various parts of The Gully and on adjacent banks. Observations of species richness, community assemblages, estimates of biomass from image analysis and calculations of respiration rates were used to assess the role of epifauna in the bioenergetics of The Gully region.

\section{MATERIALS AND METHODS}

Station locations. Bottom still photographs $(35 \mathrm{~mm}$ color slides) were obtained at 92 stations during 3 cruises ('Parizeau' 97-053, October 1997; 'Hudson' 99012, May 1999; and 'Hudson' 2000-020, June 2000) in the area of The Gully $\left(44^{\circ} \mathrm{N}, 55^{\circ} \mathrm{W}\right)$ on the eastern Scotian Shelf (Fig. 1). Duplicate or inadequate photographs (e.g. oblique camera angle or bottom obscured by turbidity) were discarded, resulting in a set of 587 images used to identify epibenthic fauna assemblages and their relation to bottom habitat types. Images from 31 stations representing both inner and outer areas along the axis of The Gully (Fig. 1, Table 1) were selected to derive quantitative relationships between bottom type, numbers of epifauna taxa, biomass, respiration and location within the canyon.

Benthic environmental physical variables. To examine possible physical habitat characteristics that might be correlated with epibenthic fauna assemblages and respiration rates, a suite of variables was analyzed for each sampling station. Water depth was recorded from the ship echosounder log at the time of sampling. Sediment type was derived from interpretation of bottom photographs (see following subsection). Simrad ${ }^{\circledR}$ EM3000 multibeam interpretation was used to confirm sediment type and calculate local slope (Fader \& Strang 2002). A grid of seasonal oceanographic variables (temperature, salin- 
Table 1. Locations in The Gully (in Fig. 1) sampled in 1997, 1998 and 2000 to assess bottom type (percent hard substrate), epifauna taxa for community composition, biomass and respiration. Percent (average \pm SD) hard substrate was based on percent bottom cover of rocks and pebbles $>4 \mathrm{~mm}$ in diameter. Depth ranges reflect drift while stations were occupied. Distance along the longitudinal axis of the canyon was calculated from the uppermost line for Region A in Fig. 1

\begin{tabular}{|c|c|c|c|c|c|c|c|}
\hline \multicolumn{2}{|c|}{ Cruise/Stn no. } & $\begin{array}{l}\text { Latitude } \\
\qquad\left({ }^{\circ} \mathrm{N}\right)\end{array}$ & $\begin{array}{l}\text { Longitude } \\
\left({ }^{\circ} \mathrm{W}\right)\end{array}$ & $\begin{array}{l}\text { Depth } \\
\text { (m) }\end{array}$ & $\begin{array}{c}\text { Distance } \\
(\mathrm{km})\end{array}$ & $\begin{array}{c}\text { No. } \\
\text { of images }\end{array}$ & $\begin{array}{c}\% \text { hard } \\
\text { substrate }\end{array}$ \\
\hline \multicolumn{8}{|c|}{ RV ‘Parizeau' 97-053 1997 (Oct) } \\
\hline 1 & 9706 & $44^{\circ} 13.510^{\prime}$ & $59^{\circ} 07.507^{\prime}$ & 200 & 4.2 & 8 & $61.2(4.2)$ \\
\hline $2^{\mathrm{a}}$ & 9707 & $44^{\circ} 13.005^{\prime}$ & $59^{\circ} 11.451^{\prime}$ & 183 & 4.8 & 7 & 0 \\
\hline $3^{\mathrm{a}}$ & 9708 & $44^{\circ} 12.678^{\prime}$ & $59^{\circ} 15.521^{\prime}$ & 152 & 4.2 & 10 & $95.5(0.3)$ \\
\hline 4 & 9709 & $44^{\circ} 10.544^{\prime}$ & $59^{\circ} 15.991^{\prime}$ & 198 & 4.8 & 8 & $28.6(4.5)$ \\
\hline 5 & 9710 & $44^{\circ} 09.428^{\prime}$ & $59^{\circ} 16.117^{\prime}$ & 284 & 6.8 & 5 & 0 \\
\hline 6 & 9720 & $44^{\circ} 03.800^{\prime}$ & $59^{\circ} 10.784^{\prime}$ & 200 & 16.9 & 2 & $88.9(0.8)$ \\
\hline 7 & 9721 & $44^{\circ} 03.910^{\prime}$ & $59^{\circ} 10.415^{\prime}$ & 301 & 15.6 & 6 & $0.1(0.3)$ \\
\hline 8 & 9722 & $44^{\circ} 04.874^{\prime}$ & $59^{\circ} 05.815^{\prime}$ & 398 & 16.1 & 9 & $54.5(7.5)$ \\
\hline 9 & 9723 & $44^{\circ} 04.871^{\prime}$ & $59^{\circ} 05.490^{\prime}$ & 429 & 16.1 & 4 & $97.6(0.4)$ \\
\hline 10 & 9724 & $44^{\circ} 05.483^{\prime}$ & $59^{\circ} 01.715^{\prime}$ & 321 & 18.2 & 5 & $2.8(1.3)$ \\
\hline $11^{\mathrm{a}}$ & 9725 & $44^{\circ} 06.263^{\prime}$ & $58^{\circ} 56.876^{\prime}$ & 144 & 18.2 & 5 & 0 \\
\hline $12^{\mathrm{a}}$ & 9728 & $43^{\circ} 56.950^{\prime}$ & $58^{\circ} 54.267^{\prime}$ & 201 & 33.8 & 7 & 0 \\
\hline 13 & 9729 & $43^{\circ} 56.489^{\prime}$ & $58^{\circ} 56.674^{\prime}$ & 451 & 33.4 & 8 & $66.8(3.9)$ \\
\hline 14 & 9730 & $43^{\circ} 55.232^{\prime}$ & $59^{\circ} 02.647^{\prime}$ & 370 & 32.5 & 6 & 0 \\
\hline 15 & 9731 & $43^{\circ} 54.875^{\prime}$ & $59^{\circ} 03.667^{\prime}$ & 150 & 32.5 & 6 & 0 \\
\hline $16^{\mathrm{a}}$ & 9732 & $43^{\circ} 53.995^{\prime}$ & $59^{\circ} 07.504^{\prime}$ & 86 & 32.5 & 5 & 0 \\
\hline $17^{\mathrm{a}}$ & 9734 & $43^{\circ} 57.496^{\prime}$ & $59^{\circ} 16.481^{\prime}$ & 44 & 22.8 & 5 & 0 \\
\hline \multicolumn{8}{|c|}{ RV ‘Hudson' 99-012 1999 (May) } \\
\hline 18 & 9914 & $44^{\circ} 03.606^{\prime}$ & $59^{\circ} 10.113^{\prime}$ & 402 & 19.4 & 6 & 0 \\
\hline 19 & 9915 & $44^{\circ} 04.073^{\prime}$ & $59^{\circ} 09.607^{\prime}$ & 441 & 18.6 & 5 & 0 \\
\hline 20 & 9916 & $44^{\circ} 04.446^{\prime}$ & $59^{\circ} 07.845^{\prime}$ & 443 & 18.6 & 7 & $12.7(22.5)$ \\
\hline 21 & 9917 & $44^{\circ} 04.972^{\prime}$ & $59^{\circ} 06.584^{\prime}$ & 383 & 16.9 & 10 & $66.9(24.5)$ \\
\hline 22 & 9918 & $44^{\circ} 04.379^{\prime}$ & $59^{\circ} 05.595^{\prime}$ & 382 & 17.8 & 9 & $81.5(4.4)$ \\
\hline 23 & 9919 & $44^{\circ} 03.095^{\prime}$ & $59^{\circ} 04.970^{\prime}$ & 398 & 22.0 & 5 & $55.9(8.2)$ \\
\hline 24 & 9920 & $44^{\circ} 02.129^{\prime}$ & $59^{\circ} 04.261^{\prime}$ & 370 & 23.6 & 5 & $10.7(11.6)$ \\
\hline \multicolumn{8}{|c|}{ RV 'Hudson' 2000-020 2000 (Jun/Jul) } \\
\hline 25 & BC1 & $43^{\circ} 55.986^{\prime}$ & $59^{\circ} 58.010^{\prime}$ & $767-776$ & 33.8 & 26 & 0 \\
\hline 26 & $\mathrm{BC} 2$ & $43^{\circ} 55.571^{\prime}$ & $58^{\circ} 58.242^{\prime}$ & 1189-1254 & 32.9 & 31 & $0.8(2.0)$ \\
\hline 27 & BC3 & $43^{\circ} 55.511^{\prime}$ & $59^{\circ} 00.861^{\prime}$ & $897-946$ & 34.2 & 17 & 0 \\
\hline 28 & BC5 & $43^{\circ} 50.988^{\prime}$ & $58^{\circ} 52.995^{\prime}$ & $1214-1240$ & 44.8 & 30 & $69.5(47.3)$ \\
\hline 29 & $\mathrm{BC} 4$ & $43^{\circ} 50.043^{\prime}$ & $58^{\circ} 57.045^{\prime}$ & $1287-1291$ & 43.9 & 1 & 0 \\
\hline 30 & BC7 & $43^{\circ} 45.101^{\prime}$ & $58^{\circ} 56.985^{\prime}$ & 1127-1142 & 51.5 & 6 & 0 \\
\hline 31 & BC8 & $43^{\circ} 42.059^{\prime}$ & $58^{\circ} 53.979^{\prime}$ & $1326-1328$ & 55.7 & 6 & $0.7(8.7)$ \\
\hline
\end{tabular}

ity, near-bottom current velocity) for the study area was provided by the Coastal Ocean Sciences Division (G. Han \& J. Loder pers. comm.). Kriging was performed to derive values for variables at sample station co-ordinates. Seasonal averages for temperature and salinity were derived as a simple variance of 4 seasonal values. There were high correlations between seasonal values of variables. To reduce redundancy, 9 variables (depth, sediment type, local slope, average annual temperature, seasonal temperature variance based on 4 seasons, average annual salinity, salinity variance, average annual near-bottom current velocity and average yearly variance of local current) were chosen for further analysis.

Photography. The majority (462 slides from 79 stations) of images of a relatively constant bottom area $\left(\sim 0.182 \mathrm{~m}^{2}\right)$ were obtained with CAMPOD—a surface tethered, benthic still photo-video camera system (Chin-Yee et al. 1997, Gordon et al. 2000). Deployment depth was limited by the length of the conducting cable to $<450 \mathrm{~m}$. A $0.5 \mathrm{~m}^{2}$ VIDEOGRAB (Chin-Yee et al. 1997, Rowell et al. 1997) provided video images of the bottom and was also used to collect individual epifauna for respiration experiments. Both CAMPOD and VIDEOGRAB were equipped with a short baseline navigation system (ORE Trackpoint II) for precise bottom positioning.

A Benthos ${ }^{\circledR}$ deep-sea camera was used during 'Hudson' 2000-020 at 7 stations (117 images) in the outer regions of The Gully, where water depth was $>450 \mathrm{~m}$ (767 to $1328 \mathrm{~m}$ ) (Table 1). The deep-water camera/flash system was lowered on a hydrowire and 
photographs were taken when a trip weight hanging $\sim 1 \mathrm{~m}$ below the camera made bottom contact. Known dimensions of the weight provided a physical scale to calculate the area photographed $\left(0.8\right.$ to $\left.1.4 \mathrm{~m}^{2}\right)$. Locations of stations photographed with the Benthos ${ }^{\circledR}$ camera were taken from a GPS log for ship position at the time of bottom contact. The stations were chosen on the basis of interpretation of sidescan sonar and multibeam bathymetry to ground-truth for the variety of features, sediment and process-related distributions within The Gully region.

Image analysis for identification of epifauna assemblages. All images were digitized (Kodak PhotoCD ${ }^{\circledR}$ ) for quantitative analysis. A FileMaker ${ }^{\circledR}$ database was created to record date, station co-ordinates, water depth, a bathymetric map of the surrounding area, and description of bottom type. Images at the highest resolution $\left(1025 \times 683\right.$ pixels, 385 pixels $\left.\mathrm{cm}^{-2}\right)$ allowed substrate features and dimensions of visible epifauna $>0.2 \mathrm{~cm}$ to be measured. All visible epifauna were identified to the lowest possible taxon. Although taxonomic resolution using photographs is limited, it was possible to confirm identifications using specimens collected by the VIDEOGRAB. Frequency of occurrence of each taxon was calculated as the ratio of the number of images where a species was present to the total number of images from the station. Use of presence/ absence data was justified, since there was a significant $(\mathrm{p}<0.05)$ positive logarithmic relationship between the frequency of occurrence (asymptotic to a maximum value of 1) and average abundance for different taxa. Numbers of taxa observed in different images were calculated on $\mathrm{a} \mathrm{m}^{-2}$ basis to allow comparisons between stations.

Image analysis for quantifying substrate type and epifauna biomass. Sediment type at all stations was coded ( 0 to 7 ) as $0=$ mud, $1=$ silty sand, $2=$ fine sand, $3=$ medium sand, $4=$ coarse sand, $5=$ winnowed till, $6=$ sand and gravel, $7=$ lag gravel. The grading system accounted for both average particle size and sediment sorting. In addition, photographs from 31 stations (270 images) were selected for detailed examination to evaluate trends in biomass with substrate type, depth (198 to $>1300 \mathrm{~m}$ ) and distance from the head of The Gully (Fig. 1, Table 1). For quantitative analysis, a simplified scale for bottom type was required that could be easily obtained from images. The percentage of the bottom covered by hard substrate (considered as visible particles in photographs $>4.0 \mathrm{~mm}$ in diameter generally including boulders, cobbles and pebbles) was selected as the basis for a 3-category hardness index. Calculated values for percentages of hard surface area were confirmed by applying a $5 \times 5 \mathrm{~mm}$ grided clear acetate sheet of the same dimensions as an image on a computer monitor and recording the number of squares covered by hard substrate. Values were classified as (1) high (>50\%), (2) medium (1 to $49 \%$ ) and (3) low (<1\%) hardness to quantify relative amounts of hard substrate for statistical treatment. Sand or muddy sediments (no rocks visible) were considered to have no hard substrate and were assigned a hardness index of 3 .

Different linear measurements were used to quantify the area covered by epifauna. For taxa such as echinoderms (brittle stars and sand dollars), the oral disc or total test diameter was measured as the area of a circle representing the size of an individual. For more rectangular, conical or cylindrical-shaped organisms (e.g. sea pens, corals), area was calculated from length and width. Areas of organisms with more complex shapes (encrusting sponges, starfish, plumose corals) were determined as a circle calculated from the average of the lengths of 4 radii emanating from a central point to the outer edge of the organism. Sea anemone area was determined as a circle across the base by measuring the linear distance across the base of the tentacles. Linear measurements and area calculations were applied to all epifauna observed.

Wet weight (WW) of individual epifauna taxa of various sizes was measured using freshly thawed or preserved specimens previously collected from The Gully or adjacent areas (Sable Island Bank and Banquereau) on the Scotian Shelf, or individuals collected from stations sampled by VIDEOGRAB during the 'Hudson' 2000-020 cruise. Corrections were applied for changes in weight due to freezing and/or preservation in alcohol and formalin solutions. Corrected weights were combined with the estimated area for individual taxa to calculate $\mathrm{mg} \mathrm{WW} \mathrm{mm}^{-2}$. Hard coral tissue biomass was determined from linear measurements of the 2 most abundant taxa (Acanella arbuscala and Keratoisis ornata) by assuming that $10 \%$ of the wet-dry weight difference (water content) was living tissue. Weight loss on drying $\left(60^{\circ} \mathrm{C}\right)$ was determined for pieces of coral following measurements of length and diameter.

While WW was used to calculate weight-specific respiration rates, other studies have normalized for size-dependent effects by expressing oxygen uptake on an ash-free or organic carbon basis (Gerlach et al. 1985, Mahaut et al. 1995). To allow comparison between studies, we applied standard conversion factors of dry weight $=10 \%$ of WW, organic matter $=80 \%$ of dry weight and organic carbon $=30 \%$ of dry tissue weight. The conversions are for calculation purposes only, since actual values for water, ash and elemental composition can be expected to vary with species. The slope coefficient in the allometric relationship between size and respiration (see following subsection) is unaffected by the choice of weight unit. 
Respiration rates and turnover time. Respiration rates were measured during the 'Hudson' 2000-020 cruise using individual epifauna collected by the VIDEOGRAB. Epifauna were removed from the grab immediately on retrieval and held in flowing seawater at ambient temperature $\left(3\right.$ to $\left.5^{\circ} \mathrm{C}\right)$ for at least $1 \mathrm{~h}$ before being placed in $1150 \mathrm{ml}$ plexiglass chambers for measurements of oxygen uptake (Cranford et al. 1999). Each chamber contained a magnetic stirring bar under a protective bottom support. Stirring bars were rotated at $15 \mathrm{rpm}$ to maintain homogenous oxygen distribution within chambers during incubations. Chambers were sealed with lids containing o-rings to avoid trapping air bubbles, and incubations were conducted in the dark at ambient bottom-water temperature. Respiration rates were calculated over 2 to $4 \mathrm{~h}$ from differences in initial and final dissolved oxygen concentrations measured using a polarographic oxygen micro-electrode held in a water jacket at the incubation temperature. Oxygen concentrations were always $>5 \mathrm{mg} \mathrm{l}^{-1}$ at the end of experiments.

Total chamber volume was corrected for organism displacement volume measured $( \pm 0.5 \mathrm{ml})$ using a graduated cylinder. Absolute changes in dissolved oxygen were based on the volume of water incubated corrected for changes in dissolved oxygen in chambers without epifauna. Organisms were frozen $\left(-18^{\circ} \mathrm{C}\right)$ in whirl-pack bags after experiments and, after thawing, blotted WW was determined using a top-loading Sartorius E925 balance $( \pm 0.1 \mathrm{mg})$ for large taxa $(>1 \mathrm{~g}$ individual $\left.^{-1}\right)$ or a Mettler AE163 $( \pm 0.01 \mathrm{mg})$ balance for smaller $(<1 \mathrm{~g})$ individuals. Respiration rates as $\mathrm{ml} \mathrm{O}_{2}$ $\mathrm{g}^{-1} \mathrm{WW} \mathrm{h}^{-1}$ were calculated from changes in total dissolved oxygen, individual wet weight and incubation time.

Mass-specific standard metabolism (R) as $\mathrm{ml} \mathrm{O}_{2} \mathrm{~g}^{-1}$ $\mathrm{h}^{-1}$ was compared with WW using the allometric equation $\mathrm{R}=a \times \mathrm{WW}^{-b}$, where $a$ and $b$ are fitted intercept and slope coefficients, respectively. An empirical regression derived by combining data from all respiration experiments was used to calculate oxygen uptake from WW of individual organisms identified in photographs from the 31 stations shown in Fig. 1. The sum of individual respiration rates normalized for image area was used to calculate epifauna community respiration $\left(\mathrm{ml} \mathrm{O}_{2} \mathrm{~m}^{-2} \mathrm{~d}^{-1}\right)$. The time in days for respiration to consume the total calories in the mass of an individual (turnover time, TT) was calculated for all individuals using conversion factors from Peters (1983). The average energy content in fresh invertebrate tissue (90\% water, $10 \%$ dry matter) was assumed to be 1680 cal g-1 with $1 \mathrm{ml} \mathrm{O}_{2}$ respired, releasing 4.8 calories. Conversion factors were applied to literature-derived values if biomass and weight-specific respiration were not based on WW: $1 \mathrm{~g}$ wet biomass contains $90 \%$ water, $1 \mathrm{kcal}$, and $50 \mathrm{mg} \mathrm{C} ; 1 \mu \mathrm{mol} \mathrm{O} \mathrm{O}_{2}$ respired $=22.4$ $\mu \mathrm{g} \mathrm{O}_{2}$ and $15.9 \mu \mathrm{O}_{2}, 1 \mathrm{ml} \mathrm{O}=20 \mathrm{~W}, 20 \mathrm{~J}, 4.85 \mathrm{cal}$ and $0.44 \mathrm{mg} \mathrm{C}$ (Banse 1979, Peters 1983, Mahaut et al. 1995). TT was calculated as the ratio of calories in tissue to calories respired by an individual per day. Mean $( \pm$ SD) TT for epifauna in all images from each station was calculated from the arithmetic mean of TT values for all individuals enumerated.

Statistical methods. Statistical analyses were performed using Systat ${ }^{\circledR}$ software (Wilkinson 1996). Classification of benthic habitat and epifauna assemblages was used to distinguish sets of physical factors with the largest influence on taxonomic composition based on non-parametric correlation analysis of dissimilarity matrices. Dissimilarity among stations, based on recognized taxa, considered all possible combinations of the 9 physical factors described in second subsection above. All physical factors were normalized ( 0 to 1 ) to construct Euclidean dissimilarity matrices. Similarity between frequencies of occurrence of different taxa was calculated using the Bray-Curtis similarity index. Rare species $<<5 \%$ occurrence), observed at $<10$ stations, were not considered. Cluster analysis was performed on the dissimilarity matrix and Ward's method of linkage was used to distinguish groups of co-occurring taxa. The resulting non-parametric correlation coefficients (Spearman's rho) between biotic dissimilarity and habitat dissimilarities based on different combinations of descriptors were ranked, and the highest correlation was considered indicative of the combination of variables that best defined community structure. Habitat electivity indices were calculated as described by Kostylev (2002) for major types of seafloor morphology in The Gully and surrounding bank areas. The index has a value of -1 if the assemblage avoids the habitat, 0 if it is as likely to be present in the habitat as in any other, and a positive value if there is preference for the habitat.

Weight-dependent standard respiration was determined by linear regression analysis. Many previous studies have reported size-specific respiration rates using linear predictive Model I regressions (Banse 1979), however this analysis is not recommended if both independent and dependent variables contain natural variability and measurement error (Ricker 1973). Model II functional (GM, geometric mean) regressions should be used to represent the slope when the independent variable is not controlled (as in the case of WW correlated with weight-specific respiration). Results using both types of models are included here to allow comparison with allometric regressions reported in previous studies.

The GM Model II slope is equal to the Model I slope/r (where $r$ is the Model I correlation coefficient) 
and the GM intercept is $y_{\text {mean }}-b x_{\text {mean }}$, where $y_{\text {mean }}$ and $x_{\text {mean }}$ are mean values of $x$ and $y$, respectively (Laws \& Archie 1981). Log-transformed values were used to calculate $x_{\text {mean }}$ and $y_{\text {mean }}$ values to derive coefficients for GM Model II regressions. Due to small sample numbers and the large ranges in calculated values, biomass, respiration rates and TT values were log-transformed prior to calculations of means $( \pm \mathrm{SD})$ for stations grouped by substrate hardness, distance along The Gully, and depth. A nonparametric 1-way ANOVA (Kruskal-Wallis) was used to test for significant differences $(p<0.05)$ among station groups.

\section{RESULTS}

\section{Classification of physical habitats}

We identified 8 visible epifauna and megafauna phyla (Echinodermata, Coelenterata, Annelida, Chordata, Mollusca, Porifera, Brachiopoda and Arthropoda, in order of decreasing abundance) and 175 taxa in photographs from all stations. Cluster analysis identified 7 assemblages that were associated with specific habitat types characterized by 4 of the 9 physical factors considered (Table 2). Depth, substrate type, seasonal temperature variance and average annual

Table 2. Epifauna assemblages identified by cluster analysis in areas within The Gully (in Fig. 1) with common habitat characteristics for each group

\begin{tabular}{|c|c|c|}
\hline Benthic assemblage & Major taxa & Predominant habitat type \\
\hline Cluster 1 & $\begin{array}{l}\text { Brittlestars Ophiomusium sp., banded } \\
\text { coral Keratoisis ornata, sea whips (likely } \\
\text { Balticina sp.), hydroids, soft alcyonacean } \\
\text { corals Anthomastus sp. }\end{array}$ & $\begin{array}{l}\text { Deep-water, mouth of The Gully, on canyon } \\
\text { walls, > } 600 \text { m depth, ridges dominated by } \\
\text { suspension feeders, depositional valleys } \\
\text { dominated by deposit-feeders }\end{array}$ \\
\hline Cluster 2 & $\begin{array}{l}\text { Infaunal brittlestar Ophiopholis sp., } \\
\text { daisy-top anemone Stomphia sp., } \\
\text { sponges, chitons, and crinoids }\end{array}$ & $\begin{array}{l}\text { Deep-water, gravelly substrate, } 250-650 \mathrm{~m} \text {, } \\
\text { relatively constant temperature and } \\
\text { high salinity along edge of canyon }\end{array}$ \\
\hline Cluster 3 & $\begin{array}{l}\text { Cerianthid anemone Cerianthus borealis, } \\
\text { shrimp (Pandalidae, Crangonidae spp.), } \\
\text { burrowing anemones, polychaetes, krill, } \\
\text { Meganyctiphanes norvegica, deposit- } \\
\text { feeding brittlestar Ophiura sp., sea } \\
\text { urchin Strongylocentrotus pallidus }\end{array}$ & $\begin{array}{l}\text { Upper Gully, } 130-410 \mathrm{~m} \text {, glaciomarine } \\
\text { deposits, microhabitats in bedrock, outcrops } \\
\text { in tributary channels, moderate salinity and } \\
\text { varying temperature }\end{array}$ \\
\hline Cluster 4 & $\begin{array}{l}\text { Sand dollar Echinarachnius parma, } \\
\text { brittlestar Ophiura sarsi, tube-dwelling } \\
\text { polychaetes (Northriidae), hermit crabs } \\
\text { Pagurus sp. and spider crabs Hyas } \\
\text { araneus, burrowing anemones } \\
\text { Edwardsia sp., gastropods (Trochidae), } \\
\text { polar sea star Leptasterias sp. }\end{array}$ & $\begin{array}{l}\text { Shallow depth }(50-300 \mathrm{~m}) \text {, sand (bank tops) } \\
\text { with highly variable oceanographic } \\
\text { conditions }\end{array}$ \\
\hline Cluster 5 & $\begin{array}{l}\text { Protozoan Bathysyphon sp., } \\
\text { burrowing brittlestar Amphioplus sp., } \\
\text { anemones, sponge Polymastia sp., } \\
\text { soft corals Alcyonacea spp., } \\
\text { sea feather Pennatula sp. }\end{array}$ & $\begin{array}{l}\text { Variable sediments (in tributary canyons), } \\
200-600 \mathrm{~m} \text { in areas with steep slopes, } \\
\text { substrates range from silty sand to till, } \\
\text { soft sediment between cobbles and } \\
\text { boulders }\end{array}$ \\
\hline Cluster 6 & $\begin{array}{l}\text { Sponges (Halichondria sp., Scypha ciliata, } \\
\text { and Crella guernei), } \\
\text { encrusting and solitary tunicates } \\
\text { (Molgulidae spp.), bryozoans (anascan } \\
\text { and ascophoran), stalked hydrozoan } \\
\text { Sertullaria sp., gastropod Buccinum sp., } \\
\text { and terebellids }\end{array}$ & $\begin{array}{l}\text { Winnowed gravel } 100-500 \mathrm{~m} \text { in areas } \\
\text { affected by shelf water with lower } \\
\text { salinity and moderately variable } \\
\text { temperature }\end{array}$ \\
\hline Cluster 7 & $\begin{array}{l}\text { Many taxa similar to Cluster } 6 \text { brachiopods } \\
\text { Terebratulina septentrionalis, white } \\
\text { encrusting sponge, anemone Fragesia sp., } \\
\text { serpullid worms Filograna implexa, and } \\
\text { Protula tubularia, tube-building } \\
\text { polychaetes (Nothriidae) }\end{array}$ & $\begin{array}{l}\text { Poorly sorted gravel (glacial till), } 100-500 \mathrm{~m} \\
\text { on top of deep banks with average salinity, } \\
\text { moderately variable temperatures and } \\
\text { strong currents }\end{array}$ \\
\hline
\end{tabular}


Table 3. Benthic habitat types identified by non-parametric correlation analysis for various areas within The Gully (in Fig. 1). Station groupings show common benthic habitat properties with respect to bathymetry, average water mass properties and bottom substrate characteristics

\begin{tabular}{|c|c|c|c|c|c|}
\hline $\begin{array}{l}\text { Station group } \\
\text { Location }\end{array}$ & $\begin{array}{l}\text { Depth } \\
\text { range }(\mathrm{m})\end{array}$ & $\begin{array}{l}\text { Sediment } \\
\text { type }\end{array}$ & $\begin{array}{l}\text { Temp. } \\
\left({ }^{\circ} \mathrm{C}\right)\end{array}$ & Salinity & $\begin{array}{c}\text { Current } \\
\text { speed }\left(\mathrm{cm} \mathrm{s}^{-1}\right)\end{array}$ \\
\hline $\begin{array}{l}\text { Group } 1 \\
\text { Adjacent to slopes, } \\
\text { canyon and tributary } \\
\text { channels }\end{array}$ & $100-450$ & $\begin{array}{l}\text { Silty-sand } \\
\text { (constant) }\end{array}$ & $\begin{array}{c}5.4 \\
\text { (constant) }\end{array}$ & $\begin{array}{c}\text { High } \\
\text { (variable) }\end{array}$ & High \\
\hline $\begin{array}{l}\text { Group } 2 \\
\text { Upper canyon slopes, } \\
\text { inner parts of } \\
\text { tributary channels }\end{array}$ & $100-450$ & $\begin{array}{l}\text { Silty-sand } \\
\text { (variable) }\end{array}$ & $\begin{array}{c}5.4 \\
\text { (constant) }\end{array}$ & $\begin{array}{c}\text { High } \\
\text { (constant) }\end{array}$ & High \\
\hline $\begin{array}{l}\text { Group } 3 \\
\text { Deep areas of } \\
\text { The Gully }\end{array}$ & $>450$ & $\begin{array}{l}\text { Mud, silty- } \\
\text { sand }\end{array}$ & 3.7 to 4.9 & $\begin{array}{l}\text { Higher } \\
\text { than other } \\
\text { groups }\end{array}$ & $\begin{array}{l}\text { Seasonally } \\
\text { variable }\end{array}$ \\
\hline $\begin{array}{l}\text { Group } 4 \\
\text { Low slope areas }\end{array}$ & $100-400$ & $\begin{array}{l}\text { Mud, medium } \\
\text { sand }\end{array}$ & $>5.4$ & $\begin{array}{c}\text { High } \\
\text { (constant) }\end{array}$ & $\begin{array}{c}\text { Low } \\
\text { (constant) }\end{array}$ \\
\hline $\begin{array}{l}\text { Group } 5 \\
\text { Upper Gully, hard } \\
\text { glacial substrate }\end{array}$ & $100-450$ & $\begin{array}{l}\text { Medium sand } \\
\text { to lag gravel }\end{array}$ & $\begin{array}{c}>5.4 \\
\text { (constant) }\end{array}$ & $\begin{array}{c}\text { High } \\
\text { (constant) }\end{array}$ & $\begin{array}{c}\text { Low } \\
\text { (moderately } \\
\text { variable) }\end{array}$ \\
\hline $\begin{array}{l}\text { Group } 6 \\
\text { Banks surrounding } \\
\text { The Gully }\end{array}$ & $<100$ & $\begin{array}{c}\text { Coarse, } \\
\text { fine sand to } \\
\text { winnowed till }\end{array}$ & $\begin{array}{c}\text { Low } \\
\text { (highly variable } \\
\text { seasonally) }\end{array}$ & $\begin{array}{c}\text { Low } \\
\text { (highly variable } \\
\text { seasonally) }\end{array}$ & $\begin{array}{l}\text { Moderate } \\
\text { (highly } \\
\text { variable) }\end{array}$ \\
\hline
\end{tabular}

salinity had the highest correlation with epifauna taxa composition.

Non-parametric correlations used to group stations identified 6 major benthic habitat types based on bathymetry, water-mass properties, and bottom substrate (Table 3). The station groups showed common characteristics based on these physical variables and represented major regions in The Gully and on adja-

Table 4. The 5 major geomorphological categories, mean number of taxa $\mathrm{m}^{-2}( \pm \mathrm{SD}, \mathrm{n}=$ number of observations $)$ and habitat electivity indices for 7 epifauna assemblages (in Table 2) in The Gully. Positive numbers (bold) for an assemblage indicate preference for a specific habitat type based on substrate geomorphology. GLA: hard glacial substrates; SIS: soft glaciomarine sediments; BED: bedforms; CHNL: channel environment (tributary channels and Gully walls); SAND: banktop sand excluding major bedforms

\begin{tabular}{|lccccc|}
\hline \multirow{2}{*}{ Assemblage } & \multicolumn{5}{c|}{ Geomorphology } \\
& GLA & SIS & BED & CHNL & SAND \\
\hline 1 & 0 & -1 & -1 & $\mathbf{2 . 1}$ & -1 \\
2 & $\mathbf{2 . 6}$ & -1 & -1 & -1 & -1 \\
3 & 0 & $\mathbf{0 . 7}$ & 0 & $\mathbf{0 . 1}$ & -1 \\
4 & 0 & 0 & $\mathbf{0 . 2}$ & -1 & $\mathbf{1 . 3}$ \\
5 & $\mathbf{1 . 9}$ & 0 & -1 & 0 & -1 \\
6 & $\mathbf{2 . 4}$ & -1 & 0 & -1 & -1 \\
7 & $\mathbf{2 . 9}$ & -1 & -1 & -1 & -1 \\
No. of taxa & 16.6 & 4.50 & 4.41 & 3.59 & 3.23 \\
SD & 6.02 & 2.26 & 5.46 & 4.45 & 3.57 \\
n & 20 & 13 & 11 & 24 & 18 \\
& & & & & \\
\hline
\end{tabular}

cent banks. Habitat electivity indices for the 7 epifauna assemblages were related to 5 major classes of seafloor morphology (hard glacial substrates, soft glaciomarine sediments, bedforms, channels and Gully walls, and banktop sands) represented in the station groupings (Table 4); 4 assemblages $(2,5,6$ and 7) dominated by sponges, tunicates, brachiopods and anemones were strongly associated with glacial deposits and glacially modified terrain (till, iceberg pits and furrows). These areas, located in the upper regions of The Gully and on the edges of tributary channels, were similar in depth range (100 to $450 \mathrm{~m}$ ) and water mass characteristics. The remaining 3 assemblages were distinctly associated with channel environments, sand and silty glaciomarine sediments. Areas of sand were dominated by the assemblage of brittle stars, hydroids and soft corals (Cluster 3). Areas of sand, primarily on banks but also in depositional valleys between ridges and in tributary channels, were dominated by sand dollars, brittle stars, sea whips, banded coral and anemones (Clusters 1 and 4). Areas with silty sand deposits were dominated by the assemblage of brittle stars, hydroids, and soft corals (Cluster 3).

Species richness (average number of taxa corrected for the total survey area at each station) was highest at approximately $180 \mathrm{~m}$ on hard glacial substrates (mean $=16.6$ taxa $\mathrm{m}^{-2}$ ) and values declined with increasing depth. Deep areas of The Gully with mud and silty-sand (Group 3 stations, Table 3) had lower numbers of taxa $\left(4.5 \mathrm{~m}^{-2}\right)$, as did tributary channels 
and Gully walls (3.6 taxa $\mathrm{m}^{-2}$ ). Assemblages on banktop sands had the lowest observed values for species richness (3.2 taxa $\left.\mathrm{m}^{-2}\right)$.

\section{Body size, respiration and turnover time}

Mean weight-specific respiration rates for various epifauna taxa varied from low values (3 to $5 \mathrm{\mu l} \mathrm{O}_{2} \mathrm{~g}^{-1}$ $\mathrm{h}^{-1}$ ) in some echinoderm species and a cerianthid anemone (Cerianthus borealis) to a similar maximum value $\left(32 \mu \mathrm{O} \mathrm{O}_{2} \mathrm{~g}^{-1} \mathrm{~h}^{-1}\right)$ in the coral Acanella arbuscala and the decapod crustacean Chionoecetes opilio (Table 5). Individual body WW and weight-specific respiration rates for combined data for all taxa showed the expected allometric relationship (Fig. 2). The slope coefficient for a predictive Model I regression (-0.394) was lower than the coefficient for a Model II (functional) regression (-0.531). In some cases measurements between individuals of the same taxa were highly variable, with a high coefficient of variation (SD/mean) for Echinarachnius parma (0.44) and

Table 5. Respiration rates measured in shipboard experiments at ambient bottom temperatures $\left(3\right.$ to $5^{\circ} \mathrm{C}$ ) for various taxa of epifauna collected by VIDEOGRAB from the Scotian Shelf in June during RV 'Hudson' 2000-020 cruise. Average values for body length or width and wet wt (WW) are indicated for total number (n) of individuals used in respiration experiments. Respiration rates are given as mean $( \pm \mathrm{SD}$ or ranges) values for $\mathrm{n}$ individuals

\begin{tabular}{|c|c|c|c|c|}
\hline Species & $\mathrm{n}$ & $\begin{array}{l}\text { Body length } \\
\text { (mm) }\end{array}$ & $\begin{array}{l}\text { WW } \\
(g)\end{array}$ & $\begin{array}{c}\text { Respiration } \\
\left(\mu l \mathrm{O}_{2} \mathrm{~g}^{-1} \mathrm{~h}^{-1}\right)\end{array}$ \\
\hline \multicolumn{5}{|l|}{ Sponges } \\
\hline Crella guernei & 3 & 85 & 16.3 & $5.3(0.4)$ \\
\hline Scypha ciliata & 2 & 49 & 9.9 & $7.1(6.1,8.0)$ \\
\hline \multicolumn{5}{|l|}{ Corals } \\
\hline Gersemia rubiformis & 3 & 15 & 11.4 & $22.3(3.5)$ \\
\hline Acanella arbuscula & 3 & 115 & 3.5 & $32.3(6.4)$ \\
\hline \multicolumn{5}{|l|}{ Coelenterates } \\
\hline Metridium senile & 1 & 6 & 17.5 & 10.8 \\
\hline Cerianthus borealis & 1 & 42 & 22.8 & 4.9 \\
\hline \multicolumn{5}{|l|}{ Molluscs } \\
\hline Mactromeris polynyma ${ }^{a}$ & 4 & 74 & 25.0 & $10.8(4.4)$ \\
\hline Placopecten magellanicus & 1 & 76 & 20.0 & 7.6 \\
\hline Buccinium spp. & 1 & 30 & 20.0 & 10.8 \\
\hline \multicolumn{5}{|l|}{ Crustaceans } \\
\hline Chionoecetes opilio & 2 & 40 & 4.5 & $31.7(17.9,56.3)$ \\
\hline \multicolumn{5}{|l|}{ Echinoderms } \\
\hline Strongylocentrotus pallidus & 4 & 67 & 83.2 & $4.5(0.6)$ \\
\hline Echinarachnius parma & 7 & 70 & 42.0 & $3.7(1.0)$ \\
\hline Ophiacantha abyssicola & 5 & 10 & 2.2 & $12.4(5.5)$ \\
\hline Ophiura sarsi & $\begin{array}{l}2 \\
2\end{array}$ & $\begin{array}{c}9 \\
23\end{array}$ & $\begin{array}{l}1.4 \\
6.6\end{array}$ & $27.4(18.7,36.1)$ \\
\hline Cucumaria frondosa & 2 & 150 & 755.0 & $3.4(3.3,3.4)$ \\
\hline Psolus spp. & 1 & 33 & 40.6 & 4.7 \\
\hline
\end{tabular}

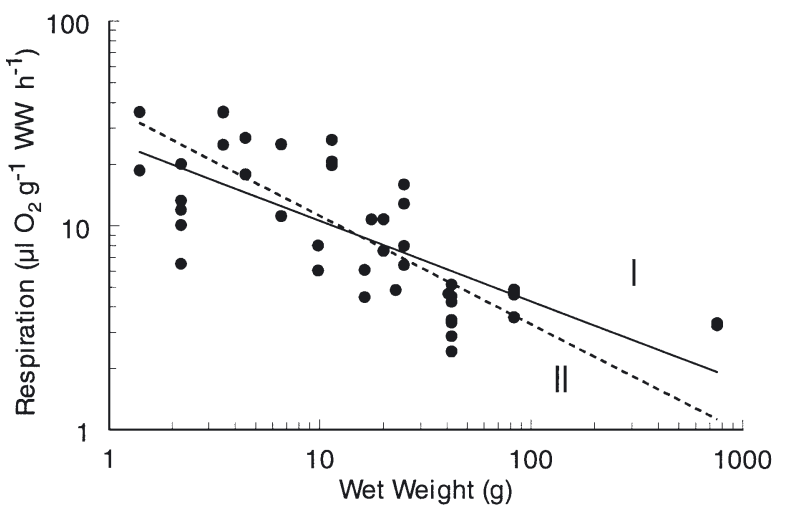

Fig. 2. Wet weight (WW) and mass-specific respiration rates (R) for various epifauna taxa collected from The Gully in June 2000. Model I (continuous line) $\left(\mathrm{R}=26.31 \mathrm{WW}^{-0.394}, \mathrm{r}^{2}=0.551\right)$ and Model II (dotted line) $\left(\mathrm{R}=38.31 \mathrm{WW}^{-0.531}\right)$. Regression Lines I and II calculated from data in Table 5

Mactromeris polynyma (0.41). In most other taxa the SD was $<20 \%$ of mean values.

Mean TT for the epifauna community at each station was calculated as the ratio of the calorific equivalent of total biomass to community respiration, derived by summing respiration rates for individual epifauna (all values on $\mathrm{a} \mathrm{m}^{-2}$ basis) using the allometric regression in Fig. 2. TT varied from a minimum (95 d) at Stn 22 in the mid-Gully region to maxima at Stn 17 on Sable Island Bank (1361 d) and at Stn 31 (1294 d) at the mouth of The Gully (Table 6).

Mean WW (g ind ${ }^{-1}$ ) for epifauna at each station, calculated by dividing total biomass by total number of individuals, was positively correlated $\left(\mathrm{r}^{2}=0.900\right)$ with TT (Fig. 3). The relationship that reflects the negative correlation between body size and weight-specific respiration (Fig. 2) allows calculation of TT from average values of individual body mass. The minimum TT value at Stn 22 (95 d) was associated with low epifauna biomass and the minimum average individual weight $(0.2 \mathrm{~g})$ for all stations. Stns 17 and 22 , on the other hand, were dominated by taxa with larger average individual size (echinoderms: brittle stars and sand dollars) (12.1 and $16.7 \mathrm{~g}$ ind. $^{-1}$, respectively). Maximum TT values reflected lower respiration rates associated with larger body size in epifauna at these 2 stations. 
Table 6. Station locations (A: inner; B: middle; and C: outer regions), substrate hardness index ( 1 : rock cover $>50 \% ; 2$ : 1 to $49 \%$; $3:<1 \%$ ), total biomass (WW), respiration from mass-specific respiration rates (Model II regression) and turnover time (TT) estimated for epifauna at 31 stations in The Gully and on Sable Island and Banquereau Banks on the Scotian Shelf (Table 1, Figs. 1 \& 2). 0: no visible epifauna in photographs from that station

\begin{tabular}{|c|c|c|c|c|c|}
\hline \multirow[t]{2}{*}{ Stn } & \multirow{2}{*}{$\begin{array}{l}\text { Location } \\
\text { (region) }\end{array}$} & \multirow{2}{*}{$\begin{array}{l}\text { Hardness } \\
\text { index }\end{array}$} & \multicolumn{2}{|c|}{ Epifauna community } & \multirow{2}{*}{$\begin{array}{l}\text { TT } \\
\text { (d) }\end{array}$} \\
\hline & & & $\begin{array}{c}\text { Biomass } \\
\left(\mathrm{g} \mathrm{WW} \mathrm{m}^{-2}\right)\end{array}$ & $\begin{array}{c}\text { Respiration } \\
\left(\mathrm{ml} \mathrm{O}_{2} \mathrm{~m}^{-2} \mathrm{~d}^{-1}\right)\end{array}$ & \\
\hline 1 & A & 1 & 27.8 & 12.2 & 489 \\
\hline $2^{\mathrm{a}}$ & A & 3 & 0 & 0 & - \\
\hline $3^{\mathrm{a}}$ & A & 1 & 306.2 & 78.5 & 456 \\
\hline 4 & A & 2 & 77.0 & 22.1 & 540 \\
\hline 5 & $\mathrm{~A}$ & 3 & 0 & 0 & - \\
\hline 6 & B & 1 & 8.6 & 3.5 & 699 \\
\hline 7 & $\mathrm{~B}$ & 3 & 3.8 & 1.9 & 454 \\
\hline 8 & B & 1 & 218.5 & 51.8 & 632 \\
\hline 9 & B & 1 & 11.6 & 11.8 & 290 \\
\hline 10 & B & 2 & 1.2 & 1.5 & 271 \\
\hline $11^{\mathrm{a}}$ & $\mathrm{B}$ & 3 & 0 & 0 & - \\
\hline $12^{\mathrm{a}}$ & $\mathrm{C}$ & 3 & 3.5 & 2.9 & 385 \\
\hline 13 & B & 1 & 39.4 & 19.9 & 527 \\
\hline 14 & $\mathrm{C}$ & 3 & 0 & 0 & - \\
\hline 15 & $\mathrm{C}$ & 3 & 4.5 & 1.3 & 885 \\
\hline $16^{\mathrm{a}}$ & $\mathrm{C}$ & 3 & 147.9 & 58.3 & 573 \\
\hline $17^{\mathrm{a}}$ & B & 3 & 53.0 & 12.7 & 1361 \\
\hline 18 & B & 3 & 0 & 0 & - \\
\hline 19 & B & 3 & 0 & 0 & - \\
\hline 20 & B & 2 & 81.7 & 12.3 & 1098 \\
\hline 21 & B & 1 & 29.4 & 4.8 & 397 \\
\hline 22 & B & 1 & 4.3 & 5.9 & 95 \\
\hline 23 & B & 1 & 49.8 & 15.8 & 407 \\
\hline 24 & B & 2 & 0 & 0 & - \\
\hline 25 & $\mathrm{C}$ & 3 & 27.1 & 4.7 & 530 \\
\hline 26 & $\mathrm{C}$ & 3 & 9.2 & 3.7 & 533 \\
\hline 27 & $\mathrm{C}$ & 3 & 2.1 & 0.7 & 754 \\
\hline 28 & $\mathrm{C}$ & 1 & 35.5 & 6.4 & 619 \\
\hline 29 & $\mathrm{C}$ & 1 & 0.5 & 0.7 & 266 \\
\hline 30 & $\mathrm{C}$ & 3 & 5.4 & 1.6 & 821 \\
\hline 31 & $\mathrm{C}$ & 3 & 39.0 & 6.3 & 1294 \\
\hline
\end{tabular}

\section{Distribution of biomass and respiration with substrate hardness and location within The Gully}

Specific epifauna assemblages were associated with characteristic benthic habitats and hydrographic variables within The Gully (Table 2). To determine if these relationships could be described by directly measured variables, data for biomass, respiration and TT was sorted by substrate hardness (3 levels), location along The Gully (3 distances) and depth (3 depth ranges)

Fig. 3. Mean individual body weight (WW) calculated from total biomass divided by total number of ind. $\mathrm{m}^{-2}$ and turnover time (TT) data presented in Table 5 for epifauna at various stations in The Gully. Model I (TT $\left.=313.25 \mathrm{WW}^{0.500}, \mathrm{r}^{2}=0.900\right)$ and Model II $\left(\mathrm{TT}=304.50 \mathrm{WW}^{0.527}\right)$ regressions shown as continuous and dotted lines, respectively
(Table 7). Due to variations between numbers of stations in different subgroups, small samples sizes and large ranges in values, data was log-transformed to calculate group means \pm SD before applying non-parametric ANOVA tests for differences between groups.

The mean value for respiration rates at stations with $<1 \%$ rock cover (substrate hardness index of 3) was significantly lower $(p<0.01)$ than averages for these variables at stations with $>50 \%$ gravel cover (Table 7, 'Substrate hardness'). A similar trend occurred for biomass and turnover times, with slightly higher p-values ( $p=0.06$ and 0.09$)$. Turnover time was most rapid (413 d) at stations with a high percentage of gravel cover. Although ANOVA p-values were higher and nonsignificant for comparisons between the 3 variables in different regions within The Gully, there was a trend towards reduced biomass and respiration rates and higher turnover times at more offshore stations (Table 7, 'Distance'). Comparisons between stations stratified by depth are confounded with distance since depth $(x)$ and distance $(y)$ were linearly correlated $(y=$ $\left.9.66+0.029 x, r^{2}=0.635\right)$ at stations where epifauna occurred. Significant differences with lower biomass and respiration and higher TT between depths $<200$ and $>500 \mathrm{~m}$ (Table 7, 'Depth') were consistent with the trend for variables with distance down The Gully. The pattern for changes in TT with both distance and depth indicated that in the intermediate range of

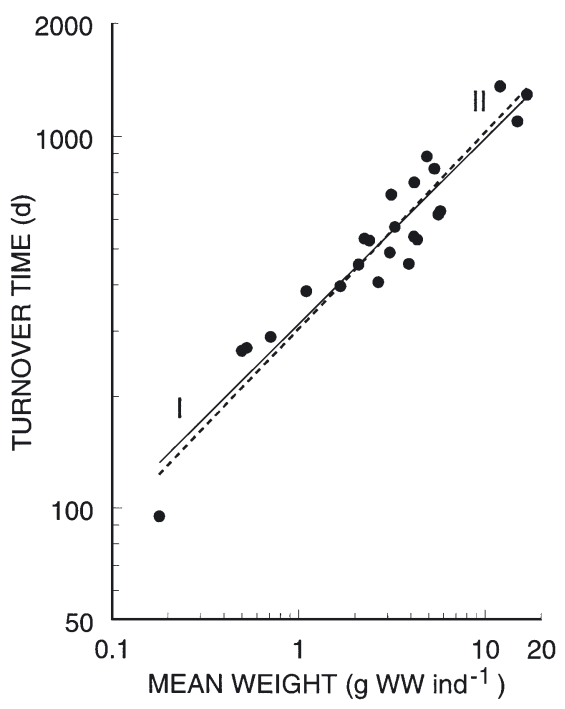


Table 7. Average $( \pm \mathrm{SD})$ values for community biomass, respiration rates and turnover times (TT) for stations with epifauna present in The Gully and on adjacent banks sorted by different criteria. Data in Table 6 were sorted by substrate hardness, distance (region, hardness categories, labelled as in Table 6) along The Gully and depth. Data were log-transformed to calculate mean values for number (n) of stations indicated. Probability values for between-category comparisons were calculated by a Kruskal-Wallis 1-way ANOVA using log-transformed data. Significant differences $(p<0.05)$ in bold

\begin{tabular}{|c|c|c|c|c|}
\hline Category & $\mathrm{n}$ & $\begin{array}{c}\text { Biomass } \\
\left(\mathrm{g} \mathrm{WW} \mathrm{m}^{-2}\right)\end{array}$ & $\begin{array}{c}\text { Respiration } \\
\left(\mathrm{ml} \mathrm{O}_{2} \mathrm{~m}^{-2} \mathrm{~d}^{-1}\right)\end{array}$ & $\begin{array}{l}\text { TT } \\
\text { (d) }\end{array}$ \\
\hline \multicolumn{5}{|c|}{ Substrate hardness (\% rock cover) } \\
\hline 1 & 10 & $32.2(12.6)$ & $12.8(5.1)$ & $413(40)$ \\
\hline 2 & 3 & $19.5(16.0)$ & $7.4(5.2)$ & $544(60)$ \\
\hline 3 & 11 & $8.8(7.2)$ & $3.0(4.0)$ & $647(47)$ \\
\hline \multicolumn{5}{|c|}{ Between-category probability values } \\
\hline $1-2$ & & 0.833 & 0.527 & 0.792 \\
\hline $2-3$ & & 0.301 & 0.218 & 0.522 \\
\hline $1-3$ & & 0.064 & 0.009 & 0.092 \\
\hline \multicolumn{5}{|c|}{ Distance (region) (km) } \\
\hline $1<10(\mathrm{~A})$ & 3 & $86.9(23.4)$ & $27.7(7.9)$ & $494(7)$ \\
\hline $210-25(\mathrm{~B})$ & 10 & $17.5(9.9)$ & $7.3(3.9)$ & $453(56)$ \\
\hline $325-56(\mathrm{C})$ & 11 & $10.6(7.4)$ & $3.8(3.9)$ & $603(40)$ \\
\hline \multicolumn{5}{|c|}{ Between-category probability values } \\
\hline $1-2$ & & 0.246 & 0.113 & 0.916 \\
\hline $2-3$ & & 0.480 & 0.192 & 0.355 \\
\hline $1-3$ & & 0.127 & 0.054 & 0.076 \\
\hline \multicolumn{5}{|l|}{ Depth (m) } \\
\hline $1<200$ & 7 & $41.1(16.7)$ & $13.2(7.5)$ & $666(40)$ \\
\hline $2 \quad 200-500$ & 10 & $15.5(9.4)$ & $7.5(4.2)$ & $388(41)$ \\
\hline $3>500$ & 7 & $7.9(6.2)$ & $2.4(2.7)$ & $625(47)$ \\
\hline \multicolumn{5}{|c|}{ Between-category probability values } \\
\hline $1-2$ & & 0.091 & 0.329 & 0.025 \\
\hline $2-3$ & & 0.369 & 0.050 & 0.191 \\
\hline $1-3$ & & 0.050 & 0.030 & 0.711 \\
\hline
\end{tabular}

epifauna biomass, respiration rates and TT with depth. However, differences with distance down The Gully were described by non-linear negative exponential regressions (Fig. 4B,D). Although there was considerable variation in the data $\left(\mathrm{r}^{2}=0.21\right.$ and 0.48 , respectively), both relationships showed that biomass and respiration decreased with increasing distance offshore down the axis of The Gully. The few stations on banks (open circles in Fig. 4B,D) showed a similar onshoreoffshore gradient. The relationship between TT and distance (Table 7, Fig. 4F) was not significant ( $p>0.05)$.

\section{General relationship between epifauna biomass and respiration rates}

Since oxygen uptake was calculated for all stations using a common weightspecific allometric regression (Fig. 2), community respiration rates depend on estimated biomass. The positive linear relationship between these 2 variables allowed community respiration to be estimated directly from biomass (Fig. 5). The small variance $\left(\mathrm{r}^{2}=0.921\right)$ in the regression indicates that respiration was determined predominantly by betweenstation differences in biomass reflecting differences in numbers and the size of individual epifauna. Although the number of stations was small, the linear relationship applies to locations both within The Gully and on adjacent banks.

\section{DISCUSSION}

described relationships between epifauna biomass, respiration rates and bottom hardness at all other stations (Fig. 4A,C). Maximum values for both variables occurred in locations with approximately 50\% rock cover. Biomass and respiration rates on banks at the head of The Gully (Stn 3) and on Banquereau and Sable Island Banks (Stns 11, 12, 17) spanned the entire range of values observed ( 0 to $306 \mathrm{~g} \mathrm{~m}^{-2}, 0$ to $78.5 \mathrm{ml}$ $\mathrm{O}_{2} \mathrm{~m}^{-2} \mathrm{~d}^{-1}$ ) (Table 6). Epifauna communities at Stn 3, where maxima for both variables were observed, were dominated by sponges and brachiopods. No significant quantitative relationship existed between TT and substrate hardness (Table 7, Fig. 4E).

Despite the indication of significant differences between stations grouped by depth (Table 7), there were no significant correlations $(p>0.05)$ between

\section{Gradients in epifauna biodiversity within The Gully}

Our observations show that epifauna communities in The Gully are associated with different substrates, reflecting the availability of hard surfaces for attachment. Highest species richness (17 taxa $\mathrm{m}^{-2}$ ) occurred on hard glacial substrates, where there was a predominance of suspension-feeding species in 4 assemblages (Tables 2 \& 4). The main canyon, tributary channels and banktop areas were not especially rich in taxa and showed similar low numbers (mean $=3.5$ ).

Species composition and the number of benthic faunal taxonomic groups are often thought to be determined by habitat structure (complexity), stability, pre- 
Fig. 4. Relationships between $(\mathrm{A}, \mathrm{B})$ epifauna biomass, $(\mathrm{C}, \mathrm{D})$ calculated community respiration rates and $(\mathrm{E}, \mathrm{F})$ turnover times (Table 6) with respect to percent of rock cover (substrate hardness) and distance (Table 1) for numbered stations shown in Fig. 1. Regression curves (Model 1) (continuous line) with upper and lower $95 \%$ confidence limits (dashed lines) are shown where significant $(p<0.05)$ correlations were present. Data from bank areas (0) were not included in regression calculations. (A) $\ln y=$ $1.76+0.11 x-0.0011 x^{2}, \mathrm{r}^{2}=$ $0.466) ;(B) y=160.3-0.80$ $\left.\ln (x), r^{2}=0.176\right) ;(C) \quad(\ln y=$ $0.78+0.08 x-0.0008 x^{2}, r^{2}=$ $0.560) ;(D) \quad y=75.6-0.88$ $\left.\ln (x), r^{2}=0.380\right)$
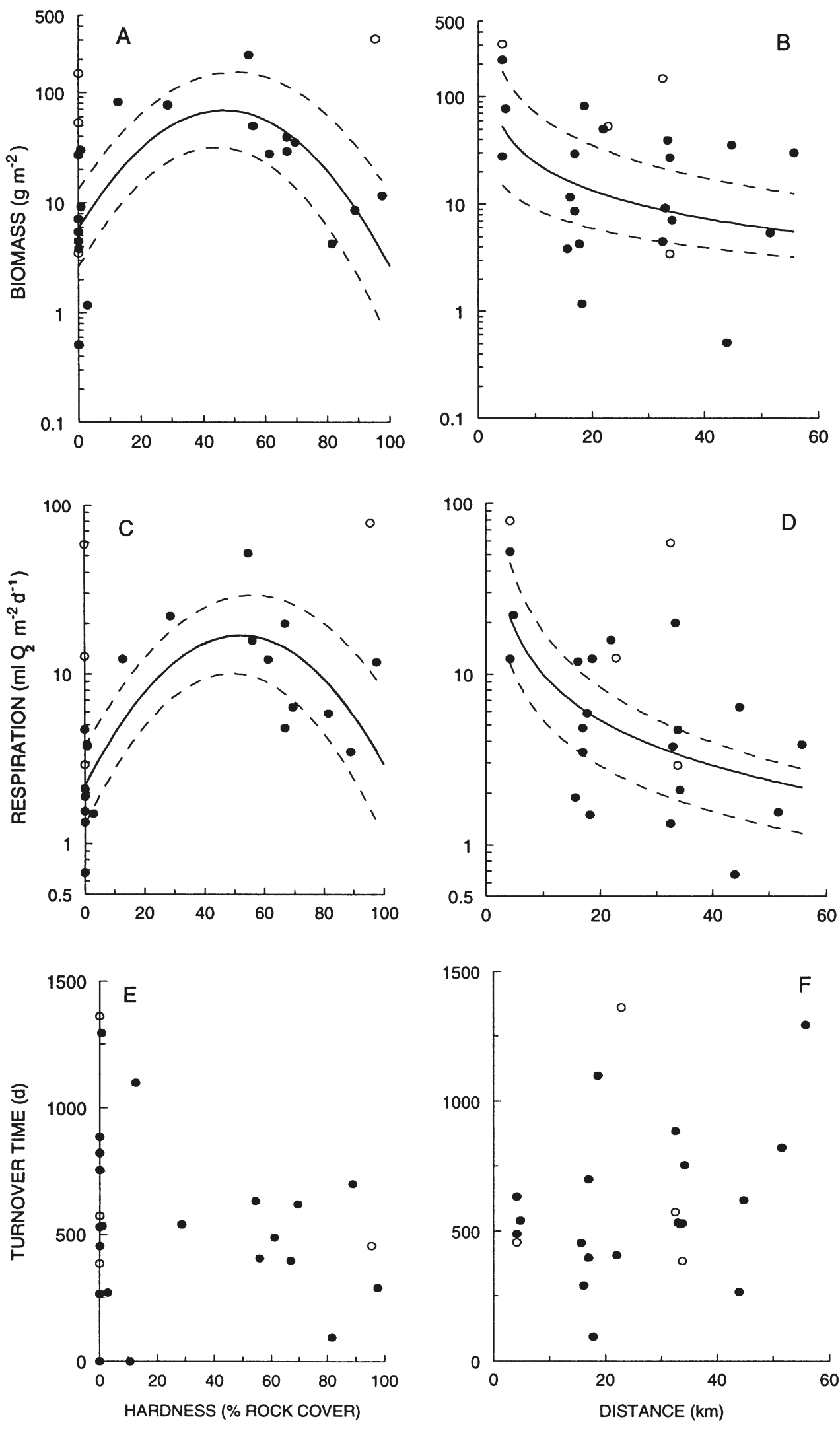


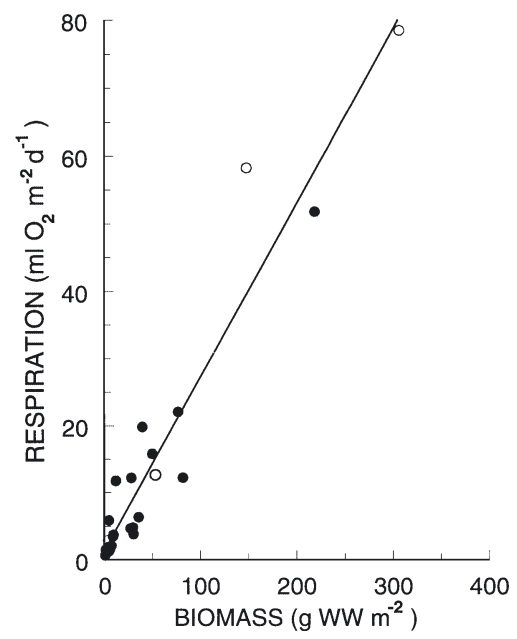

Fig. 5. Epifauna biomass (B) and community respiration rates (R) from data in Table 6. Model II regression from Fig. 2 was used to calculate epifauna community respiration rates. Linear regression $\left(\mathrm{R}=1.44+0.258 \mathrm{~B}, \mathrm{r}^{2}=0.921, \mathrm{n}=24\right)$ analysis included data from all stations where epifauna biomass was measured within The Gully (•) and on adjacent bank areas (O)

dation and other factors, while biomass is regulated by food supply (Sibuet et al. 1989, Snelgrove \& Butman 1994). Observations of epibenthic megafauna community structure and biomass on continental shelves and slopes off New England and east Greenland support this generality. Canyons on NW Atlantic continental shelves (Hecker et al. 1980, Rowe et al. 1982, Houston \& Haedrich 1984) and in the NE Atlantic (Duineveld et al. 2001) show variations from rock and gravel on the margins to silt in deeper areas. As in our study, distribution patterns of species assemblages and richness were best correlated with seafloor characteristics quantified by the presence of hard surfaces (e.g. number of stones) (Haedrich et al. 1975, 1980, Hecker et al. 1980, Hecker 1990a, Mayer \& Piepenburg 1996). Recent observations on Browns Bank on the western Scotian Shelf have also shown that dominant benthic epifauna species assemblages are associated with distinct habitat types based primarily on regional geomorphology, sediment texture and water-mass characteristics (Kostylev et al. 2001). Current speed and habitat complexity (relative sea floor cover by boulders, gravel, sand and shell hash) determined the biodiversity and predominance of major suspension- and deposit-feeding megafauna taxonomic groups.

If sediment transport occurs along the main axes of the channels of The Gully as described by Fader \& Strang (2002), sediment deposition may occur on shelves and bedrock outcrops. This could create an unstable habitat for attachment by large benthic species and lead to abrupt discontinuities in assemblages over depth (Hecker 1982, 1990a). In contrast, we found that glacial deposits within and along surrounding channel edges supported diverse populations of attached suspension-feeding epifauna such as soft alcyonacean and hard gorgonian corals. Species richness was maximum near $180 \mathrm{~m}$, where the abundance of hard substrate was greatest. The decline in numbers of taxa with increasing depth reflects both changes in substrate type (decreased availability of hard surfaces) and, perhaps, decreased food supply.

\section{Epifauna respiration and turnover times}

Specific respiration measured in our study declined with increasing body size, as expected from general allometric relationships between body size and oxygen consumption (Peters 1983) (Fig. 2). Average $(95 \%$ CI) slope and intercept coefficients for Model I $(a=26.3, \mathrm{CI}$ 18.5 to $37.3 ; b=-0.39, \mathrm{CI}-0.51$ to 0.28 ) and Model II $(a=38.3$, CI 25.3 to $58.0 ; b=-0.53$, CI -0.68 to -0.38 ) regressions in the present study are within the ranges previously reported for a wide variety of marine invertebrates (Table 8).

Differences in intercept values are more pronounced than differences between slope coefficients (Table 8) which might reflect differences in temperature. The mean $( \pm \mathrm{SD})$ value for a $(34.0 \pm 10.1)$ for epifauna from shallow-water areas reported by Banse (1979), Peters (1983) and Mahaut et al. (1995), where respiration was measured between 10 and $20^{\circ} \mathrm{C}$, is 1.7 times higher than the average value $(19.6 \pm 14.6)$ derived from studies with deeper water epifauna (Mahaut et al. 1995, Schmid 1996, Takeuchi \& Watanabe 1998) where incubation temperatures were between -1 and $5^{\circ} \mathrm{C}$. The increment is close to an expected $Q_{10}$ value of 2 (doubling with a $10^{\circ} \mathrm{C}$ rise in temperature) often used to correct for effects of variable temperature on respiration (Heip et al. 2001). Additional variation may be attributed to taxa-specific differences. The value for the infaunal bivalve mollusc Astarte montagui ( $a=1.2$, Schmid 1996) contrasts with much higher values for the mobile scavenging amphipod Eurythenes gryllus ( $a=33.4$, Takeuchi \& Watanabe 1998), and 2 coral species, the decapod Chionoecetes opilio and the brittle star Ophiacantha abyssicola $(a=28.4 \pm 4.6)$ (Table 5).

Individual epifauna body size and TT (Fig. 3) are not independent variables since both respiration and average TT at each station were calculated using the same estimate of numbers and biomass. The allometric relationship between body size and weight-specific respiration forms the underlying basis for the correlation between the 2 variables. Despite this co-variance the regression is useful for quantifying changes in epifauna TT with body size. Since the community average TT expresses the ratio of calories in biomass to 


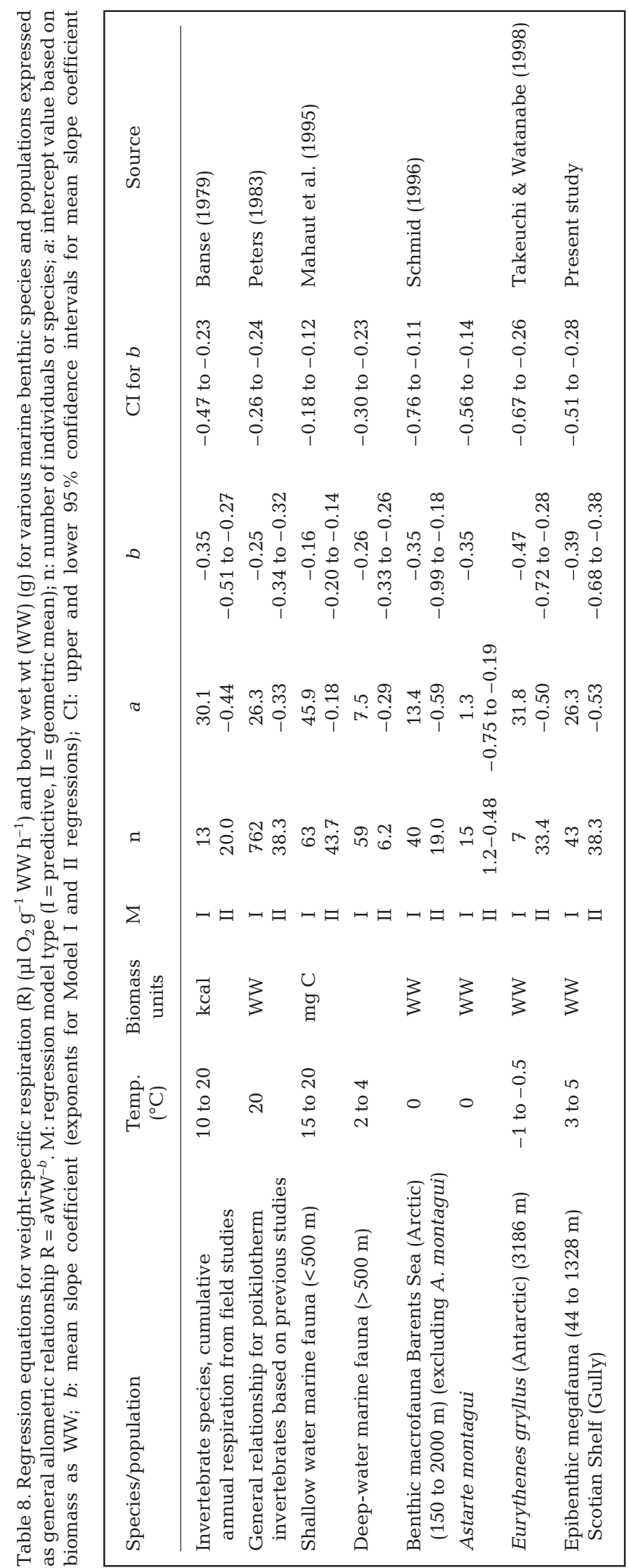

respired energy, the relationship could be used in future studies in The Gully when mean individual sizes of epifauna are determined. The empirical relationship in Fig. 3 could be used with estimates of average size of visible epifauna to estimate TT without the necessity for direct measurements of respiration. Stations dominated by individuals of relatively small body size, irrespective of total biomass, will have more rapid turnover rates. The relationship could be used to map potential food resource distribution for epifauna within The Gully.

\section{Epifauna biomass, respiration, turnover time and inferred organic matter flux}

Our estimates of epifauna community biomass and respiration rates (maximum $306.2 \mathrm{~g} \mathrm{WW} \mathrm{m}^{-2}$, $78.5 \mathrm{ml} \mathrm{O}_{2} \mathrm{~m}^{-2} \mathrm{~d}^{-1}$ ) (Table 6) are in the upper range of published values where similar photographic methods were used to estimate megafauna distribution in northern latitude shelf-slope environments over a comparable depth range (to approximately $1000 \mathrm{~m}$ ) (Table 9). As in the present study, benthic megafauna biomass and respiration rates on banks and in more shallow coastal shelf areas $(<100 \mathrm{~m})$ (Piepenburg et al. 1995, Piepenburg \& Schmid $1996 \mathrm{~b}, 1997)$ tend to be higher than at deeper ( $>500 \mathrm{~m}$ ) depths (Christiansen et al. 2001, Heip et al. 2001).

A survey of total benthic metabolism measured as sediment oxygen uptake off eastern Canada (Grant et al. 1991) showed that rates of oxygen uptake by fine-sediment bottom types in basins on the shelf and continental slope were 2.7 times greater than values measured in coarser sandy sediments on banks. Oxygen consumption in sediment-core samples is dominated by bacteria, meiofauna and small infauna, and contributions of epifauna to estimated oxygen demand are not represented. Our data and published observations (Table 9) show an opposite trend for epifauna, whereby both biomass and respiration are higher in more shallow water. Decreased epifauna biomass and respiration with increasing depth in most studies was not observed in the NW Barents Sea (Piepenburg et al. 1995), where biomass and respiration rates in deep slope areas were higher than on adjacent shelves, possibly due to off-shelf transport of organic matter in this area. Stations with highest values for epifauna biomass and hence high respiratory demand in The Gully (Table 9) were usually dominated by echinoderms (brittle stars, sand dollars and holothurians) as observed in 
Table 9. Average $( \pm \mathrm{SD})$ values of biomass (WW) ( $\mathrm{g}$ wet wt $\mathrm{m}^{-2}$ ), respiration $(\mathrm{R})\left(\mathrm{ml} \mathrm{O}_{2} \mathrm{~m}^{-2} \mathrm{~d}^{-1}\right)$ and turnover time (TT) $(\mathrm{d})$ for benthic megafauna communities in various coastal and deep-water northern boreal and arctic marine locations. In most studies megafauna was comprised primarily of echinoderms (ophiurids, holothurians) and coelenterates (anemones), molluscs and crustaceans, if present, were usually a small proportion of total biomass

\begin{tabular}{|c|c|c|c|c|c|}
\hline Location & $\begin{array}{l}\text { Depth } \\
\text { (m) }\end{array}$ & $\begin{array}{l}\text { Biomass } \\
\text { (WW) }\end{array}$ & $\begin{array}{l}\text { Respiration } \\
\text { (R) }\end{array}$ & $\begin{array}{l}\text { Turnover time } \\
\text { (TT) }\end{array}$ & Source \\
\hline \multicolumn{6}{|l|}{ NW Barents Sea } \\
\hline Shallow shelf & $<240$ & $39.1(10.0-99.2)$ & $1.8(0.5-4.0)$ & $7603(7000-8880)$ & \multirow[t]{2}{*}{ Piepenburg et al. (1995) } \\
\hline Deep slope & $190-1010$ & $65.2(1.0-131.0)$ & $8.8(1.0-13.9)$ & $3458(350-3299)$ & \\
\hline \multicolumn{6}{|l|}{ NE Greenland Shelf } \\
\hline Banks (depth 95 m) & $40-150$ & $31.0(18.0-105.0)$ & $21.7(0.2-36.3)$ & $500(1012-31500)$ & \multirow[t]{4}{*}{ Piepenburg \& Schmid (1996b) } \\
\hline Trans (depth $205 \mathrm{~m}$ ) & $100-580$ & $8.0(1.8-10.5)$ & $2.0(0.2-11.4)$ & $1400(322-3150)$ & \\
\hline Slope (depth $305 \mathrm{~m}$ ) & $180-440$ & $2.0(0.5-11.0)$ & $0.7(0.7-3.1)$ & $1077(1167-1242)$ & \\
\hline Deep water (depth $510 \mathrm{~m}$ ) & ) $0-770$ & 0.5 & 0.1 & 2188 & \\
\hline Laptev Sea shelf & $14-45$ & $10.2(0-12.2)$ & $5.6(0.7-10.5)$ & $638(50-407)$ & Piepenburg \& Schmid (1997) \\
\hline \multicolumn{6}{|l|}{ NE Atlantic Ocean } \\
\hline Iceland Basin & 2900 & 5.7 & 0.8 & 2494 & \multirow[t]{2}{*}{ Christiansen et al. (2001) } \\
\hline West European Basin & $3800-4550$ & 1.8 & 1.1 & 573 & \\
\hline \multicolumn{6}{|l|}{ NE Atlantic (Goban Spur) } \\
\hline Celtic Sea shelf & $208-231$ & 1.1 & 0.9 & 436 & Heip et al. (2001) \\
\hline Porcupine Abyssal Plain & 670 & 1.1 & 0.8 & 526 & \multirow[t]{6}{*}{ Heip et al. (2001) } \\
\hline & 1034 & 1.1 & 0.6 & 666 & \\
\hline & 1425 & 1.1 & 0.5 & 714 & \\
\hline & 2182 & 0.7 & 0.3 & 1000 & \\
\hline & 3670 & 0.8 & 0.2 & 1428 & \\
\hline & 4460 & 0.5 & 0.2 & 1000 & \\
\hline \multicolumn{6}{|c|}{ NW Atlantic (Scotian Shelf Gully) } \\
\hline Banks & $<200$ & $41.1(24.4-57.8)$ & $13.2(5.7-20.7)$ & $666(456-1361)$ & \multirow[t]{3}{*}{ Present study (Table 7) } \\
\hline Canyon & $200-500$ & $15.5(6.1-24.9)$ & $7.5(3.3-11.7)$ & $388(95-1098)$ & \\
\hline Deep slope & $>500$ & $7.9(1.7-14.1)$ & $2.4(0.5-5.1)$ & $625(266-1294)$ & \\
\hline
\end{tabular}

other subarctic and northern boreal areas (Piepenburg et al. 1995, Piepenburg \& Schmid 1996a).

The gradient of decreased epifauna biomass and respiration with increasing depth and offshore distance along The Gully appears to be less than that over a similar depth range in other locations (Piepenburg \& Schmid 1996b, Heip et al. 2001) (Table 9). Smaller depth gradients also occur in deeper $(>1000 \mathrm{~m})$ areas of the NE Atlantic (Iceland Basin, West European Basin, and Goban Spur) (Christiansen et al. 2001, Heip et al. 2001). This could reflect the expected reduction in supply of fresh organic matter when water depths exceed $1000 \mathrm{~m}$. However, seasonal ice cover in highArctic seas, which might also be expected to limit supply of organic matter from pelagic production, does not appear to be reflected in reduced epifauna biomass or respiration. Piepenburg \& Schmid (1997), Piepenburg et al. (1997) and Rowe et al. (1997) cite observations in various high-Arctic shelf ecosystems that show increased biomass of epifauna in polynyas where high rates of primary production transport relatively fresh organic matter to the benthos.

Although the range in published values is large, measures of epifauna TT in The Gully are similar to previous calculations for benthic megafauna (Table 9). The general pattern of increasing TT with increasing depth, apparent within individual studies, would be expected if particulate matter reaching the seafloor at deeper depths becomes increasingly refractory due to reduction of labile organic matter by bacterial activity on sinking material. As in The Gully, depth and distance offshore co-vary in many study locations. Both offshore distance and increasing depth could limit fresh organic matter being supplied to suspension and surface sediment feeding megafauna by downslope transport (Hecker 1990b).

Structural and functional information on benthic communities is seldom combined due to limitations and restricted spatial scales inherent in sampling equipment and experiment methods (Grant \& Schwinghamer 1987). However, our observations show that the analysis of bottom photographs and video images, used to determine taxonomic composition, abundance and size of visible organisms, can be combined with estimates of respiration to infer spatial patterns of organic matter flux to epifauna communities. Our observations suggest that organic matter used by suspension- and deposit-feeding epifauna in The 
Gully originates inshore and is transported down the axis of the canyon. Highest epifauna biomass, comprised primarily of anemones, sponges and soft corals, occurred on glaciomarine deposits, where the supply of organic matter coincided with abundant hard surfaces for attachment.

Acknowledgements. We thank C. Bourbonnais, K. MacIsaac, S. Fuller and R. van Soest for confirmation of taxonomic identifications and assistance with area/weight determinations, W. P. Vass, K. Bentham and H. Wiele for operation of the underwater camera systems, P. Cranford for use of metabolic chambers for respiration measurements and G. B. J. Fader for help with description and interpretation of bottom-sediment characteristics. G. B. J. Fader, P. B. Mortensen and L. BuhlMortensen provided useful comments and suggestions on the manuscript.

\section{LITERATURE CITED}

Amos CL (1989) Submersible observations of Quaternary sediments and bedforms on the Scotian Shelf. Geol Surv Can Pap 88-20:9-26

Banse K (1979) On weight dependence of net growth efficiency and specific respiration rates among field populations of invertebrates. Oecologia 38:111-126

Chin-Yee MB, McKewon DL, Steeves GD (1997) Proven equipment for selectively sampling the seafloor. In Oceans '97 MTS/IEEE Conference Proceedings, Oct 6-7, 1997, Halifax, NS, p 380-385

Christiansen B, Beckmann W, Weikert H (2001) The structure and carbon demand of the bathyal benthic boundary layer community: a comparison of two oceanic locations in the NE-Atlantic. Deep-Sea Res 48:2409-2424

Cranford PJ, Gordon DC Jr, Lee K, Armsworthy SL, Tremblay GH (1999) Chronic toxicity and physical disturbance effects of water- and oil-based drilling fluids and some major constituents on adult sea scallops (Placopecten magellanicus). Mar Environ Res 48:225-256

Duineveld G, Lavaleye M, Berghuis E, de Wilde P (2001) Activity and composition of the benthic fauna in the Whittard Canyon and the adjacent continental slope (NE Atlantic). Oceanol Acta 24:69-83

Fader GBJ, Strang J (2002) An interpretation of multibeam bathymetry from The Gully, outer Scotian Shelf: materials, habitats, slopes, features and processes. Can Tech Rep Fish Aquat Sci 2377:5-16

Fenton DG, Macnab PA, Rutherford RJ (2002) The Sable Gully marine protected area initiative: history and current efforts. In: Bondrup S, Murray NWP, Nelson G, Wilson JHM, Herman TB, Eagles P (eds) Managing protected areas in a changing world. SAMPAA, Wolfville, p 1342-1355

Gerlach SA, Hahn AE, Schrage M (1985) Size spectra of benthic biomass and metabolism. Mar Ecol Prog Ser 26: 161-173

Gordon DC Jr, Fenton DG (2002) Advances in understanding The Gully ecosystem. Can Tech Rep Fish Aquat Sci 2377:vi + 84

Gordon DC Jr, Kenchington ELR, Gilkinson KD, McKeown DL and 5 others (2000) Canadian imaging and sampling technology for studying marine benthic habitat and biological communities. In: CM 2000/T:07. ICES 2000 Annual Science Conference, 27-30 September 2000, Bruges
Grant J, Schwinghamer P (1987) Size partitioning of microbial and meiobenthic biomass and respiration on Browns Bank, south-west Nova Scotia. Estuar Coast Shelf Sci 25: 647-661

Grant J, Emerson CW, Hargrave BT, Shortle JL (1991) Benthic oxygen consumption on continental shelves off eastern Canada. Cont Shelf Res 11:1083-1097

Haedrich RL, Rowe GT, Polloni PT (1975) Zonation and faunal distribution of epibenthic populations on the continental slope south of New England. J Mar Res 33:191-212

Haedrich RL, Rowe GT, Polloni PT (1980) The megabenthic fauna in the deep sea south of New England, USA. Mar Biol 57:165-179

Han G, Roussel P, Loder JW (2002) Seasonal-mean circulation and tidal currents in the Gully. Can Tech Rep Fish Aquat Sci 2377:39-48

Harrison WG, Fenton DG (1998) The Gully: a scientific review of its environment and ecosystem. Can Stock Assess Sect Res Doc 98/83:282

Hecker B (1982) Possible benthic fauna and slope instability relationships. In: Saxov S, Nieuwenhuis JK (eds) Marine slides and other mass movements. Plenum Press, New York, p 335-347

Hecker B (1990a) Variation in megafaunal assemblages on the continental margin of New England. Deep-Sea Res 37: $37-57$

Hecker B (1990b) Photographic evidence for the rapid flux of particles to the sea floor and their transport down the continental slope. Deep-Sea Res 37:1773-1782

Hecker B, Blechschmidt G, Gibson P (1980) Epifaunal zonation and community structure in three mid- and North Atlantic Canyons. Final Report for the Canyon Assessment Study in the mid- and North Atlantic Areas of the US Outer Continental Shelf. US Department of Interior Bureau Land Management, Washington, DC, p 1-139

Heip CHR, Duineveld G, Flach E, Graf G and 11 others (2001) The role of the benthic biota in sedimentary metabolism and sediment-water exchange processes in the Goban Spur area (NE Atlantic). Deep-Sea Res 48:3233-3243

Houston KA, Haedrich RL (1984) Abundance and biomass of macrobenthos in the vicinity of Carson submarine canyon, Northwest Atlantic Ocean. Mar Biol 82:301-305

Jacques Whitford Environmental (2001) Characterization of benthic habitat in the Annaplois Block Exploratory License 2377. Report to Marathon Canada Ltd Project No NSD15430, $14 \mathrm{p}$

Keizer P (1998) The Gully science review. Canadian Stock Assessment Proceedings Ser 98/2. Fisheries and Oceans Canada, Bedford Institute of Oceanography, Dartmouth, NS, $40 \mathrm{p}$

Kepkay P, Harrison WG, Bugden JBC, Poter CJ (2002) Seasonal plankton production in The Gully ecosystem. Can Tech Rep Fish Aquat Sci 2377:61-68

Kostylev VE (2002) Benthic assemblages and habitats of The Gully. Can Tech Rep Fish Aquat Sci 2377:17-30

Kostylev V, Todd BJ, Fader GBJ, Courtney RC, Cameron GDM, Pickrill RA (2001) Benthic habitat mapping on the Scotian Shelf based on multibeam bathymetry, surficial geology and sea floor photographs. Mar Ecol Prog Ser 219: 121-137

Laws EA, Archie JW (1981) Appropriate use of regression analysis in marine biology. Mar Biol 65:13-16

Mahaut ML, Sibuet M, Shirayama Y (1995) Weight-dependent respiration rates in deep-sea organisms. Deep-Sea Res 42:1575-1582

Marlow JLI (1965) Probable Tertiary sediments from a submarine canyon off Nova Scotia. Mar Geol 3:263-268 
Mayer M, Piepenburg D (1996) Epibenthic community patterns on the continental slope off East Greenland at $75^{\circ} \mathrm{N}$. Mar Ecol Prog Ser 143:151-164

Mills EL, Fournier RO (1979) Fish production and the marine ecosystems of the Scotian Shelf. Mar Biol 54:101-108

Nesis KN (1965) Biocoenoses and biomass of benthos of the Newfoundland-Labrador region. Trudy VNIRO 57: 153-483. Fish Res Board Can Transl Ser 2591:1-30

Peters RH (1983) The ecological implications of body size. Cambridge University Press, Cambridge, UK

Piepenburg, D, Schmid MK (1996a) Brittle star fauna (Echinodermata L Ophiuroidea) of the Arctic northwestern Barents Sea: composition, abundance, biomass and spatial distribution. Polar Biol 16:383-392

Piepenburg D, Schmid MK (1996b) Distribution, abundance, biomass, and mineralization potential of the epibenthic megafauna of the Northeast Greenland shelf. Mar Biol 125:321-332

Piepenburg D, Schmid MK (1997) A photographic survey of the epibenthic megafauna of the Arctic Laptev Sea shelf: distribution, abundance, and estimates of biomass and organic carbon demand. Mar Ecol Prog Ser 147:63-75

Piepenburg, D, Blackburn TH, von Dorrien CF, Gutt J and 6 others (1995) Partitioning of benthic community respiration in the Arctic (northwestern Barents Sea). Mar Ecol Prog Ser 118:199-213

Piepenburg D, Ambrose WD Jr, Brandt A, Renaud PE, Ahrens MJ, Jensen P (1997) Benthic community patterns reflect water column processes in the Northeast Water Polynya (Greenland). J Mar Syst 10:467-482

Piper DJW, Mudie PJ, Fader GB, Josenhans HW, McLean B, Vilks G (1990) Quaternary geology. Geol Survey Can Report 2: 475-607

Pocklington P, Tremblay MJ (1987) Faunal zones in the northwestern Atlantic based on polychaete distribution. Can J Zool 65:391-402

Ricker WE (1973) Linear regression in fisheries research. J Fish Res Board Can 30:409-434

Editorial responsibility: Richard Haedrich (Contributing Editor), St. John's, Newfoundland, Canada
Rowe GT, Polloni PT, Haedrich RL (1982) The deep sea macrobenthos on the continental margin of the Northwest Atlantic Ocean. Deep-Sea Res 29:257-278

Rowe GT, Boland GS, Escobar Briones EG, Cruz-Kaegi ME, Newton A, Piepenburg D, Walsh I, Deming J (1997) Sediment community biomass and respiration in the Northeast Water polynya, Greenland: a numerical simulation of benthic lander and spade corer data. J Mar Syst 10:497-515

Rowell TW, Schwinghamer P, Chin-Yee M, Gilkinson K and 11 others (1997) Grand Banks otter trawling experiment. III. Sampling equipment, experimental design, and methodology. Can Tech Rep Fish Aquat Sci 2190:viii+36

Sandstrom H, Elliott J (2002) Tidal mixing and The Gully ecosystem. Can Tech Rep Fish Aquat Sci 2377:49-56

Schmid MK (1996) On the distribution and oxygen consumption of ecologically important benthic animals in the waters around Svalbard (Arctic). Ber Polarforsch 202

Sibuet M, Lambert CF, Chesselet R, Laubier L (1989) Density of the major size groups of benthic fauna and trophic input in deep basins of the Atlantic Ocean. J Mar Res 47: 851-867

Snelgrove PVR, Butman CA (1994) Animal-sediment relationships revisted: cause versus effect. Oceanogr Mar Biol Annu Rev 32:111-177

Stewart PL, Levy HA, Hargrave BT (2001) Database of benthic macrofaunal biomass and productivity measurements for the eastern Canadian continental shelf, slope and adjacent areas. Can Tech Rep Fish Aquat Sci 2336:vi+31+A 1-6

Takeuchi I, Watanabe K (1998) Respiration rate and swimming speed of the necrophagous amphipod Eurythenes gryllus from Antarctic deep waters. Mar Ecol Prog Ser 163:285-288

Wildish DJ, Wilson AJ, Frost B (1989) Benthic macrofaunal production of Browns Bank, Northwest Atlantic. Can J Fish Aquat Sci 46:584-590

Wilkinson L (1996) Systat 6.0 for Windows, Statistics. SPSS, Chicago

Submitted: March 19, 2003; Accepted: December 2, 2003 Proofs received from author(s): April 2, 2004 